\title{
A Review: Vegetative Propagation of Mango (Mengifera indica L.) Through Grafting
}

\author{
Krishan Kumar Singh ${ }^{1 *}$, JS Chauhan ${ }^{2}$ and JMS Rawat ${ }^{3}$ \\ ${ }^{1}$ Department of Agriculture, Career Point University Kota Rajasthan, India \\ ${ }^{2}$ Department of Seed Science and Technology, Chauras Campus, HNB Garhwal University, India \\ ${ }^{3}$ Government Degree College, Rudraprayag, India
}

Submission: August 17, 2018; Published: September 17, 2018

*Corresponding author: Krishan Kumar Singh, Department of Agriculture, Career Point University Kota Rajasthan, India, Email: forekrishna@gmail.com

\begin{abstract}
Mango can be propagated by both sexual and vegetative methods. Among different vegetative methods of propagation like veneer grafting, epicotyl grafting, and side grafting are being adopted in different parts of India. Factors like varieties, time of grafting, method, growing conditions, defoliation period of scion, age of the scion, leaf and node retention on rootstock etc. influenced the success and survivability of mango grafts. Rainy season grafting in mango shows best results of growth and survival percentage compared to other seasons of grafting. Inarching, veneer grafting, side and wedge grafting methods are most common, but the stone grafting method is easy, cheap and rapid method to produce high quality and quantity in comparatively less time and area. In comparison to different budding and grafting methods, softwood grafting gave maximum success. This method is broadly used in the states like Maharashtra, Karnataka and Kerala. Higher graft success was obtained during the months of July-August, September and October. The success of grafting depends on the season, age of rootstock and scion, preparation of scion before grafting, cultivars, height of grafting and media used in stone grafting methods. Epicotyl grafting technique plays a vital role in the success of graft union and the advantages is that the germinating seedlings are in juvenile condition and the cells have the potentiality of quick differentiation.
\end{abstract}

Keywords: Mango; Propagation; Grafting; Survival

\section{Introduction}

Mangifera indica L. (Mango) is one of the most dominant fruit crops cultivated all over India belongs to family Anacardiaceae. It is national fruit of India and also called the king of fruits. All stages of fruit like immature, mature and ripe, used because of its excellent delicious taste and nutritive value. Young and unripe fruits is acidic in nature and used for culinary, preparing pickle, chutney and amchoor. The ripe fruits used widely and also used for preparing several products like, jams, squashes, jellies, custard powder, syrup, nectars, toffee, baby food etc.

Mango trees cultivated in both tropical and subtropical areas. Moderate rain falls, favours its growing from June to October and rainless dry weather from November onwards. Rains during preflowering and flowering period lead to delayed flowering and increase vegetative growth. Flowering season of mango trees is induced by temperature level of climatic condition. Mango is produced throughout the world specially in the countries like Philippines, Indonesia, Thailand, Burma, Malaya, Shri Lanka, Egypt, South- East Africa, Israel, Tropical Australia, USA (Hawaii and Florida). In India, mango is cultivated in almost all the states, while UP, MP, Bihar and Andhra Pradesh are the leading states in area and production. Other states where mango cultivation exists include Orissa, West Bengal, Karnataka, Gujarat, Maharashtra, Madhya Pradesh, Tamil Nadu, Kerala and Punjab. Districts of Uttar Pradesh, like Lucknow and Amroha (City of Mango) are very famous in mango production and producing lots of varieties of mango.

The farmers generally use seed for mango propagation. Mango can be propagated by both sexual and asexual (vegetative) methods. Hartmann et al. [1] reported that varietal purity can't be maintained by growing plants from its seed. These plants take decade for fruiting and the canopy covers larger area. While the vegetative propagation is best because it retains the characteristics of the mother plant, and get flower and fruit earlier, to remain comparatively smaller with the benefit of more plants accommodation per unit area. It yields earlier and much higher economic returns. In India, the grafting techniques was practiced since ancient times. But different methods of propagation like veneer grafting, epicotyl grafting, and side 
grafting are being adopted in different parts of India. However, stionic relationship is an important factor for successful graft production.

Singh et al. [2] concluded that success rate of veneer grafting in open conditions was higher in July to August. Therefore, it is very necessary to evaluate time on success of veneer grafting in mango. Bhan et al. [3] standardized the epicotyl grafting in mango at the Horticulture Research Station, Krishnanagar and they claimed about 75-80 \% success by using germinating seed as a rootstock and semi-mature terminal shoot as a scion. In epicotyls grafting young seedlings are used as rootstock for grafting.

Epicotyl grafting was successfully used as an efficient, economic and rapid method for the propagation of mango [3-4]. Side grafting, also known as Nakamura method, was formerly popular [5-6]. Mild weather condition in the absence of strong winds, intense heat and heavy rain is highly effective for this method [7], and success has also varied (50-100\%) with different cultivars [8]. In India side grafting is generally practiced in humid, coastal areas.

\section{Season of Grafting}

Singh \& Shrivastava [8] reported that the best results $(84 \%$ take) were obtained with inarching and soft wood grafting both in July. [9] reported that the best month for grafting were June, July and August, during which $100 \%$ take could be expected. [10] obtained in trials with the cv. Dashehari, softwood grafting on 20th August gave the highest grafting success (90\%) compared with $67 \%$ in July and $70 \%$ in late September.

Khalil et al. [11] observed that the time of grafting was found best between May and September. [12] recorded 92\% success of veneer grafting during the rainy season. Patil et al. [13] at Dharwad observed that when stone grafting in mango done during first week of July using 7 to 10-day old seedling as rootstock, Mulgoa gave 100 per cent successful graft while Alphonso, Pairi and Totapari, recorded 40.00, 53.33 and 53.33 per cent grafting success, respectively [14]. Observed that the highest average sprout length was recorded under June grafting and survival after 180 days was highest in August grafting.

Kumar et al. [15] conducted an experiment at Ranchi to study the effect of stone grafting in mango and observed the best growth and survival (79\%) of grafted plants in the treatment with used scions, which had been defoliated for 8 days and stored for 3 days before grafting in the rainy season. Nayak \& Sen [16] reported that the percentage of success was also greater $78.8 \%$ when it was done in July- August compared with 75\% in JanuaryMarch. However, overall rate of growth was greater in winter grafted plants. Jacob et al. [17] reported that the higher graft success $(90 \%)$ was obtained during the months of July-August, September and October. Pandey and Singh at Varanasi observed the greatest sprouting of scion (76.33\%) and subsequent survival $(40.22 \%)$ of stone-grafted mango cv. Amrapali when grafted on 16th August. Prasanth et al. [18] studied epicotyl grafting in mango and reported that grafting in the first fortnight of July resulted earliest sprouting (28.71 days), while grafting in the first fortnight of August recorded late sprouting (35.10 days) under North- Eastern dry zone of Karnataka.

Veneer grafting performed on 10th August was found to be the best technique in terms of sprouting percentage after one $(89.62 \%)$ and six (82.30\%) month of grafting [19].

\section{Effect of Variety}

Singh et al. [20] observed that the Dashehari gave significantly higher average sprouting success (65-90\%), average number of leaves (8.27) and survival after 6 months (65.35\%) than Langra in July. Radha et al. [21] reported that the height of the plants varied from $26.3 \mathrm{~cm}$ in Chandrakaran to $36.5 \mathrm{~cm}$ in Bangalora at 6 months. Karim [22] reported that the highest success was in Sindhu (80.12\%) followed by Fazli and Hybrid-10 (73.05\%) and $(68.32 \%)$ respectively and the lowest was in Gopalbhog (55.25\%). Bobade et al. [23] reported that the maximum values of growth parameters like height of sprout $(6.02 \mathrm{~cm})$, length of shoot $(27.97 \mathrm{~cm})$, length of secondary roots $(23.73 \mathrm{~cm})$ were also observed in grafts of variety Mallika and it was closely followed by grafts of variety Kesar. The maximum value of stionic ratio (0.93) was recorded in grafts of variety Pairi and it was at par with variety Amrapali (0.91).

Similar experiments have been carried out by different workers in different plant species on various parameters of grafting and success percentage with minimum time with respect to the various [24-37].

\section{Methods of Grafting}

Singh and Srivastava [38] studied on softwood grafting in mango and recorded highest success (84\%) in July. They also studied softwood grafting for two years from July to September and March to April. Better success was recorded in August (90\%). Observed that grafting in the warm humid months of June and July gave the highest survival (72-78\%). Singh \& Suryanarayana [39] studied softwood grafting in mango from June to October in Andaman and obtained the higher grafting success (87\%) during the month of August.

Results revealed that veneer grafting was the best while forkert budding was the most suitable method in terms of bud break, survival, sprout length, leaf emergence and final success [40-41]. Sabeky [42] reported that the highest percentage of grafting success $(67.2 \%)$ was obtained with grafting on 4 April. Side and softwood grafting produced higher success rates 65.8 and $63.7 \%$, respectively than shield budding (47.5\%), after 90 days. Jana [43] reported that the maximum leaf number was observed in Tommy Atkins and Amrapalli. In recent times, many detached methods of grafting have been successfully used as an efficient economic and rapid method of propagation of mango $[16,44-46]$. 


\section{Scion Characteristics}

Prasad et al. [47] studied certain aspects of veneer grafting in mango (Mangifera indica L.) cv. Banganapally in Tirupati they recorded that the Precured scions gave higher success (78.96\%) than non-precured scions (52.75\%). Success was highest (71.08\%) with 100 days old scions and lowest (62.67\%) with 120 days old scions. The mean graft survival after potting was 75.39\% with precured scions and 52.28\% with non-precured scions that high mortality often occurs when material grafted in the nursery is lifted and potted after grafting.

Kumar et al. [48] reported that the high success in veneer and cleft grafting ( $>85 \%$ ) of mango. Alam et al. [49] reported that the minimum success $(10.0 \%)$ was recorded in BARI Aam-3 grafted onto 5 and 30 days old seedlings. The tallest shoots $(25.07$ and $24.73 \mathrm{~cm}$ consecutively) were produced by Langra grafted on 15 and 20 days old seedlings. Maximum final success (76.67\%) was recorded in $10.0 \mathrm{~cm}$ long scions followed by $7.5 \mathrm{~cm}$ long ones $(70.00 \%)$ in variety Langra.

Majumder et al. [50] reported that the Grafting experiment on splice and wedge methods was carried out between August and November and, up to $80 \%$ success was achieved with splice grafting but survival was poor. Singh \& Srivastava [51] conducted several trials on factors affecting success in veneer grafting in mango. They stated that the best results were obtained from 6 months old scions, grafted on 2 years old rootstocks in July/ August. The bud sticks were defoliated and kept in moss wrapped with polythene for 3-5 days before grafting. Among the several tying materials polythene strips gave the best results.

Vegetative propagation of mango was described by Iqbal [52] in Fiji. He pointed out that cleft and side wedge grafting by using 5-6 mm large scion of the same diameter on the rootstock, were the most successful way of getting mango grafts. He also observed that grafting under $50 \%$ shade was more successful (50-95\% success) than grafting in exposed condition.

\section{Root Stock Attributes}

Geetha et al. [53] observed that the Grafting success was highest (96.67\%) in Muvandan and Chandrakaran grafted with cv. Neelam during June and survival was highest (76.67\%) in Puliyan grafted with cv. Banganapally during August. The grafted seedlings at 18 to 24 months of age were planted out in January. The results showed that rootstock Carabao survived all temperatures in both grafting combinations [54]. Islam et al. [45] reported that scions of mango cultivars Amrapali and Gopalbhog grafted on two-year-old rootstocks on 16 May gave the highest survival rates (56.82 and $52.98 \%$ ). The survival and growth of scion and rootstock were evaluated at 120 days after grafting. Rootstock growth was most pronounced $(44.57 \mathrm{~cm})$ with grafting on 15 April. Among the cultivars, higher survival (66.13\%) was recorded for Amrapali.

The maximum number of sprouted grafts, maximum sprouting percentage, minimum days for leaf emergence, maximum number of leaves per graft, girth (above the union), minimum mortality (\%) and maximum survival (\%) of grafts when grafts were made on $6 \mathrm{~cm}$ height of rootstock. Consequently, maximum growth in terms of height and girth (below the union) were recorded in grafts made on $10 \mathrm{~cm}$ height of rootstock of mango cv. Kesar [55]. Among the growing media used in the study the soil +sawdust was found to be the best growing mixture in respect of sprouting, survival and overall performance of stone grafts over other growing mixtures [56].

\section{Conclusion}

All the above investigation shows that cleft grafting method is better than the other vegetative propagation method for mango development. So, increasing the production of mango fruit grafting is one of the easy processes for developing the mango plant as soon as possible.

\section{References}

1. Hartmann HT, Kester DE, Davies FT, Geneve RL (1997) Plant Propagation Principles and Practices, 6th Ed. Hall, Eaglewood Cliffs, Massachussets, USA.

2. Singh MP, Gill SS, Khanjuriya HN (1989) Standardization of propagation techniques in mango. Acta Horticulture 231: 179-181.

3. Bhan KC, Samander HN, Yadav PS (1969) Chip budding and stone grafting of mangoes in India. Tropical Agric Trinidad 46(3): 247-253.

4. Amin RS (1978) In-situ softwood grafting in mango. Indian Hort 23(3): 9-10.

5. Burns W, Prayag SM (1921) The Book of Mango, Bulletin 103, Department of Agriculture, Bombay, India.

6. Pope WT (1929) Mango culture in Hawaii. Hawaii Agric Exp Stn Bull 58: p. 27.

7. Rao VNM (1967) Propagation Practice. The Mango Handbook, ICAR. Pp. 32-69.

8. Veeraraghvan H (1945) Side grafting in mangoes. India J Hort 3: 45.

9. Ram AP, Bist LD (1982) Studies on veneer grafting of mango in ari Punjab Hort J 22(1\&2): 64-71.

10. Singh NP, Srivastava RP (1982) Studies on various factors involved in soft wood grafting in mango. Progressive Hort 14(2\&3): 117-120.

11. Khalil FA, Hamoouda AM, Bondik AZ, El-Din IS (1983) Ann Agric Sci Ain Shams Univ 28: 1677-1688.

12. Dhaandar DG (1985) Acta Hort 108: 285-286.

13. Dhaandar DG (1985) Study on propagation of cashew nut with wedge grafting. Journal of Plantation crops 108: 285-286.

14. Patil AA, Cadigeri BG, Nalawadi UG (1991) Response of mango varieties to stone grafting. Curr Res Agril Sci 20(2): pp. 135-136.

15. Brahmchari VS, Kumar N, Kumar R (1997) Seasonal effect on success of veneer grafting in mango cv. Amrapali. Hort J 10 (2): 1-5.

16. Nayak G, Sen SK (2000) Seasonal influence of Veneer grafting of Mango (Mangifera indica L.). Environment and Ecology 18(1): 156-158.

17. Kumar R, Singh C, Jain BP (1999) Stone grafting in mango (Mangifera indica Linn.) and effect of defoliation and storage of bud-wood. Journal of Research Birsa Agricultural University 11(1): 75-76.

18. Jacob S, Ray DP, Sahu GS, Chandra A (2001) Studies on the success of soft wood grafting in some commercial hybrid mango (Mangifera indica L.). Orissa Journal of Horticulture 29(2): 6-9. 
19. Prasanth JM, Reddy PN, Pampanagouda B, Patil SR (2006) Effect of Cultivars and Time of Grafting on Per Cent Success and Survival Percentage Of Veneer Grafting In Mango (Mangifera Indica L.). Internat J Agric Sci 2(1): 19-21.

20. Syed SU, Sunil M, Ranjeet K, Mukesh K (2017) Effect of Time and Technique of Grafting for Quality Production of Nursery Plants of Dashehari Mango (Mangifera indica L.). Int J Curr Microbiol App Sci 6(10): 685-690.

21. Sing AR, Pandy SP, Sing RK, Sing ND (1992) Influence of cultivar and period of operation on the success of veneer grafting in mango. Adv Hort Forestry 19(2): pp. 17-23.

22. Radha T, Aravindakshan K (2000) Differential response of mango varieties to epicotyl grafting on commercial scale. Acta-Horticulturae 509: 265-268.

23. Karim MR (2004) Effect of leaf and node retention in rootstock on grafting in mango. M.Sc. (Ag.) thesis, Hort Dept BAU Mymensingh 3053.

24. Bobade DH, Ingole RH, Kadam AS (2018) Effect of Different Scion Varieties of Mango on Growth and Biomass Production per Formance of Stone Grafts (Mangifera indica L.). Int J Curr Microbiol App Sci Special Issue-6 pp. 1642-1648.

25. Ram S, Sirohi SC (1989) Performance of Dashehari mango trees propagated by different vegetative methods. Acta Horticulturae 231: 210-215.

26. Chakrabarty U, Sadhu MK (1989) Anatomy of graft union in epicotyl grafting of mango. Acta Hort 231: 182-185.

27. Chakrabarty U, Sadhu MK (1983) Effect of grafting time, variety and nature of scions on the success of epicotyl grafting in mango. Indian J Agril Sci 53(8): 637-641.

28. Gunjate RT (1989) Standardization of stone grafting for the Konkan region. Acta Horticulturae 231: 164-167.

29. Kashyap R, Shrivastava SS, Sharma AB (1989) Studies on vegetative propagation of mango. Acta Hort 231: 263-265.

30. Ahmad S (1964) Propagation of mango by veneer grafting. WPJ Agri Res 2: 32-44.

31. Ahmad K (1974) Review of Research in the Division of Horticulture. Bangladesh Agricultural Research Institute, Joydebpur, Gazipur pp. 3842.

32. Kulwal LV, Tayde GS (1989(a)) Studies on propagation of mango by stone grafting- Extent of mortality. Acta Hort 231: 249-251.

33. Kulwal LV, Tayde GS (1989(b)) Studies on propagation of mango varieties by soft wood grafting under Akola condition. Acta Hort 231: 256-258.

34. Singh NP, Srivastava RP (1980) A new approach towards double grafting in mango. Current Sci 49(17): 678-679.

35. Madalageri MB, Hulamani NC, Patil VR (1989) Response of mango varieties and hybrids to epicotyl grafting. Progressive Hort 21(1\&2): 173-175.

36. Majumder PK (1989) Recent advances in propagation and rootstock research in mango- World situation. Acta Hort 231: 157-163.

37. Rahim MA, Choudhury MSH, Ali MA (1984) Studies on veneer grafting in four cultivars of mango. Bangladesh Hort 12(1): 17-20.

38. Reza MH, Guha D, Shakur MA (1994) Comparison of different methods of grafting in mango. Ann Rep Bangladesh Agric Res Inst Gazipur p. 376.
39. Singh NP, Srivastava RP (1980) A new approach towards double grafting in mango. Current Sci 49(17): 678-679.

40. Singh DB, Suryanarayana MA (1996) Studies on softwood grafting in mango. Flora and Fauna 21: 83-84.

41. Nayak G, Sen SK (2000) Evaluation of vegetative propagation methods of mango. Environment and Ecology 18(1): 243-245.

42. Nayak G, Sen SK (2000) Seasonal influence of age of rootstock on veneer grafting of mango. Environment and Ecololgy 18(1): 156-158.

43. Sabeky E (2005) Study and determination of the best time and method for mango grafting in Bahokalate, Sistan Balouchestan Province. Journal of Science and Technology of Agriculture and Natural Resources 9(1): 91-101.

44. Jana BR (2007) Response of different mango cultivars to top-veneer grafting. Journal of Research Birsa Agricultural University 19(1): 9194.

45. Sivudu BV, Reddy MLN, Baburatan P, Dorajeerao AVD (2014) Effect of structural conditions on veneer grafting success and survival of mango grafts (Mangifera indica cv. Banganpalli). Plant Archives 14(1): 71-75.

46. Islam MN, Rahim MA, Farooque AM (2004) Standardization of time and grafting techniques in Mango under Bangladesh condition. Asian Journal of Plant Sciences 3(3): 378-386.

47. Vanaja L, Swami DV, Prasanna Kumar B, Subbaramamma P (2017) Effect of Grafting Time on Growth and Success Rate of Guava (Psidium guajava L.) Wedge Grafts Grown under Shade Net and Poly House Conditions. Int J Curr Microbiol App Sci 6(10): 771-779.

48. Prasad PV, Suryanarayana V, Naidu N (1990) Studies on certain aspects of veneer grafting in mango (Mangifera indica L.) cv. Banganapally. South Indian Horticulture 38(1): 1-7.

49. Kumar S, Sant R, Singh CP (2000) Success of veneer and cleft grafting a different grafting heights of seedling rootstocks in Dashehari mango. Indian Journal of Horticulture 57(3): 212-214.

50. Alam MA, Mortuza MG, Uddin MZ, Sarker D, Barman JC (2006) Effect of length and variety of scion in stone grafting of mango. International Journal of Sustainable Crop Production 1(2): 7-11.

51. Majumder PK, Mukherjee SK, Rathore DS (1972) Further researches on propagation techniques in mango. Acta Hort 24: 72-76.

52. Singh NP, Srivastava RP (1979) Studies on the different aspects involved in veneer grafting in mango. Prog Hort 11(1): pp. 67-74.

53. Iqbal M (1982) Review of Mango research and Propagation in Fiji Agril j 44(1): pp. 21-26.

54. Geetha TK, Valsalakumari PK, Geetha CK, Rajeevan PK (1997) Influence of polyembryonic rootstocks on the success and survival of soft wood grafts on mango. Journal of Applied Horticulture Navsari 3(1/2): 8588.

55. Ribeiro IJA, Soares NB, Pettinelli JA, Dudienas EC (2002) Behaviour of rootstocks of mango (Mangifera indica L.) subjected to low temperature conditions. Revista Brasileira de Fruticultura 24(1): 249-250.

56. Nalage NA, Magar SD, Bhosale SS, Mhetre DA (2010) Effect of height of rootstock on success of grafting in mango (Mangifera indica L.) cv. Kesar. International Journal of Agricultural Sciences 6(1): 124-128.

57. Prabhat K, Nidhika K (2012) Effect of age of rootstock and different growing media on the success of stone grafting in mango. International Journal of Farm Science 6(1): 255-261. 
This work is licensed under Creative Commons Attribution 4.0 License DOI: 10.19080/JOJHA.2018.01.555583
- Quality Editorial service

- Swift Peer Review

- Reprints availability

- E-prints Service

- Manuscript Podcast for convenient understanding

- Global attainment for your research

- Manuscript accessibility in different formats ( Pdf, E-pub, Full Text, Audio)

- Unceasing customer service

Track the below URL for one-step submission https://juniperpublishers.com/online-submission.php 